\title{
Bureaucracy Performance in Public Services in Indonesia
}

\author{
Yusriadi $^{1}$, Umi Farida ${ }^{2}$ \\ ${ }^{1}$ Department of Law Science, Sekolah Tinggi Ilmu Hukum Pengayoman \\ Department of Economy, Sekolah Tinggi Ilmu Ekonomi Amkop \\ Email: yusriadi.yusriadi@uqconnect.edu.au
}

(Received: March-2019; revised: April -2019; published: June-2019)

\begin{abstract}
Bureaucracy is a tool that plays an essential role in the implementation of development in the region. One of the reform agenda is to create a clean government, and free from the practices of corruption, collusion, and nepotism. Performance-based management is the measurement of bureaucratic performance oriented to outcome measurement. The type of research used is literature. The primary data type is data in the form of scientific work related to employee performance, web pages that discuss performance, while corresponding main data are books or other literature that supports and has to do with research. From the results of the study is one of the significant challenges of the public bureaucracy is how to be able to carry out activities effectively and efficiently. By going to a planned change, it will enable a continuous process of change; thus the performance of the government bureaucracy in public service will be more effective and efficient following the expectations and aspirations of the community. The application of good governance with information technology-based can use as a strategy and guidance in providing services to the public.
\end{abstract}

Keyywords: Bureaucracy; Bureaucratic Performance; Public Services;

\section{INTRODUCTION}

The era of globalization has had an impact on various aspects of human life, on the one hand bringing climate more open to filling and completing multiple things, on the other hand, the situation of competition is getting tighter and tighter. One of the reform agenda is to create a clean government, and free from the practices of corruption, collusion, and nepotism. In realizing this, of course, the role of the organization as a source of absorbing labor as an organizational unit has not been by what is required. They are influencing by the ability of individuals or employees themselves, as well as environmental conditions that shape attitudes, behaviors, and habits that pay less attention to quality.

The role of the organization in improving management functions is the duty of each leader to encourage and motivate each subordinate to excel. Organizational achievement, determined by the qualifications possessed, such as education, experience, personal characteristics. Performance is the result or output of a process (Akib, Guntur, \& Salam, 2016; Jamaluddin, Salam, Yunus, \& Akib, 2017; Nurlaila, 2010; Salam, 2015; Salam \& Rosdiana, 2016). Quality human resources are human beings who have physical abilities, non-physical abilities related to intelligence, and mental attitude, ability to work, productive, and creative, skilled, disciplined, and innovative, and oriented towards the future. Therefore the aspect of human resources is the main thing for improving the performance of an organization. A

Copyright (C) 2018 Universitas Negeri Makassar. This is an open access article under the CC BY license (http://creativecommons.org/licenses/by/4.0/) 


\author{
18 Jurnal Administrare: Jurnal Pemikiran Ilmiah dan Pendidikan Administrasi Perkantoran \\ Volume 6 Number 1 January-June 2019. Pages 17-24
}

structured organization must follow a growing and modern era and make adjustments to the demands of the times that continue to change.

The process of a bureaucratic structure is one of the supporting factors in achieving a balance between existing resources and functions needed to make a higher performance. Organizations in the bureaucracy if successful in carrying out their duties, then the government should give severe recognition and if possible give awards in any form. Bureaucratic performance is one of the essential determinants in achieving the development goals; it is also a benchmark for the success of the bureaucracy in carrying out the duties and jobs that are its responsibility. The administration is a device that plays an essential role in the implementation of development in the region. Therefore government agencies are expected to have a satisfactory performance so that they can provide excellent service to the community. Thus, human resources are the key to successful public service organizations must get primary attention in improving service quality (M. S. Saggaf, Akib, Salam, Baharuddin, \& Kasmita, 2018; S. Saggaf, Salam, Kahar, \& Akib, 2014; Yusriadi, Sahid, Amirullah, Azis, \& Rachman, 2019).

The primary function of the bureaucracy is implementing laws and policies that apply to a country. In performing this performance, an administration will automatically face challenges that need to be considered and controlled professionally. Performance the quantity or quality of something produced or services provided by someone who does the work (Luthans, 2005). Need for skilled workers in various fields is already a demand for the global world that cannot postpone. We should realize that we are required to have the ability to make quality human resource development plans. When it is time for us to succeed in overcoming the monetary crisis, our human resources should be ready to enter the era of free competition as an era of unlimited exchange of goods and services so that human resources are prepared to compete and developed economies.

To overcome these complex problems bureaucracy can make improvements in, one of which is through the development of human resources. The growth of these internal conditions also aims to strengthen them and increase resilience in the face of local and global competition which will be tighter; this means that the bureaucracy must improve its performance.

\title{
METHOD
}

The type of research used is literature. The primary data type is data in the form of scientific work related to employee performance, web pages that discuss performance, while corresponding main data are books or other literature that supports and has to do with the discussion of research.

\section{RESULT AND DISCUSSION}

Performance-based management is one part of public sector reform or also known as new public management. The focus of performance-based management is the measurement of the performance of public sector organizations that oriented towards measuring outcomes. The performance-based approach characterized by the emergence of organizational and 
management theory such as the classical organization theory model, scientific management, zero-based budgeting, and reinventing government. Bureaucratic reform is a systematic, integrated and comprehensive effort to realize good governance, including institutional aspects, apparatus human resources, management, accountability, supervision, and public service (Yusriadi, 2018a). In this study the performance measuring factor is seen from four indicators, namely 1) effectiveness and efficiency; 2) authority; 3) discipline; 4) initiative.

\section{Effectiveness and Efficiency}

If a particular goal can finally achieve, we may say that the activity is useful, but if the consequences not sought, the movement assesses the importance of the results obtained so that satisfaction even if useful is called inefficient. Conversely, if the results found are not essential or trivial, the activity is efficient (Prawirosentono, 1999; Simatupang \& Akib, 2007, 2011).

With the existence of bureaucratic reforms that have implemented in Indonesia, which has been running for 21 years, shows a positive thing about the effectiveness and efficiency of bureaucracy in providing services to the public. The administration is expected to be an efficient and effective bureaucracy and able to respond to all phenomena of governance. The bureaucracy must now indeed implement an efficient and effective bureaucracy by building a lean organization, but it can react to all aspects of achieving good management and oriented to the welfare of society.

Bureaucratic reform interpreted as a significant change in the organizational paradigm and governance. Current bureaucratic performance has been able to show efficiency and effectiveness to the community, improve efficiency both cost and time, and be able to make anticipatory, proactive and effective bureaucracy in the face of the dynamics of strategic environmental change (Anonim, 2018; Dharma \& Patar, 2012; Sancoko, 2011). As an example of improving bureaucratic performance in service, an innovation in the form of "public service malls" has begun to emerge in the regions. A mall that has an integrated public service center concept is considered to be suitable for the development of the era that demands all efficiency and concise.

Data from the Ministry of Bureaucratic Reform State Empowerment shows that there are currently nine public service malls inaugurated in the 2017-2018 period. The public service malls that opened were in Surabaya, Banyuwangi, Jakarta, Batam, Denpasar, Bekasi, Tomohon, Bitung, and Karangasem (Ashari, 2018). Public service mall inspired by Azerbaijan, all bureaucratic and administrative systems has concentrated in one place. Mall public service is concrete because people come to a site with certainty. Licensing affairs that could have been for months and weeks can now complete in a matter of hours (Ashari, 2018).

\section{Authority}

Authority is the nature of communication or order in a formal organization that belongs to an organization member to other members to carry out a work activity by its contribution (Prawirosentono, 1999). Performance is the result of the success of a person as a whole during a certain period in carrying out tasks compared to various possibilities, such as the standard of work, target and have agreed upon (Rivai \& Basri, 2005).

The government continues to make changes to the right authority so that the objectives of the bureaucracy are efficient, effective, and clean and the target to serve achieved. So far, 


\section{Jurnal Administrare: Jurnal Pemikiran Ilmiah dan Pendidikan Administrasi Perkantoran Volume 6 Number 1 January-June 2019. Pages 17-24}

bureaucratic problems still occur, both at central and regional government institutions. Indonesian society is a multicultural society that consists of a variety of different traits and behaviors. In a system of government in Indonesia, various regulations needed that can regulate the lives of these diverse Indonesian people. Although sometimes the rules made by the government are not by the wishes and expectations of the community.

The community must continue to follow and uphold the rules made by the existing bureaucratic system. So that unwittingly the authority will influence and dominate the development of a method of government. The existence of power in a government becomes very important when a government requires a rule that contains orders or prohibitions against the people and government leaders to be able to run well and harmoniously.

\section{Discipline}

Authority is the nature of communication or order in a formal organization that belongs to an organization member to other members to carry out a work activity by its contribution employee discipline is the activity of the employee concerned in respecting the work agreement with the organization where he works. Control is obedient to applicable laws and regulations (Prawirosentono, 1999; Sarman, Akib, \& Niswaty, 2015). Discipline must be one of the main foundations in the practice of governance, in the Decree of the Minister of State Apparatus Empowerment Number 25 / KEP / M.PAN / 4/2002 concerning Guidelines for the Development of the Work Culture of Apparatus. It has suggested that cultural values should be able to color the behavior of state apparatus to improve performance and quality of public services that are oriented the realization of good governance as a vision of bureaucratic reform (Joeliono, 2017).

The starting point to support the implementation of bureaucratic reform in the field of staffing must be initiated and addressed by the enforcement of work discipline and work ethic of the Civil Servants itself. To improve bureaucratic control, Government Regulation Number 53 of 2010 concerning bureaucratic discipline has established. But in its implementation, not all staff managers and superiors know and understand the meaning contained in it, so that there is still a process of disciplinary violations that are not by the provisions.

Therefore, workshops need to hold that are related to solving cases of violations of bureaucratic discipline. This workshop, carried out to provide insight into knowledge and understanding in conducting guidance, and the imposition of disciplinary penalties for employees, so that as superiors can understand the procedure in solving disciplinary violations if there are subordinates who commit disciplinary violations (WV, 2016). In general, the discipline of civil servants has increased. Can be seen from employee absences such as in Jakarta, where only less than 5 percent of employees do not enter during the first day of work after the leave together and Eid holidays. The discipline level of employees is quite high, which not as much as last year where almost 30 percent (MenpanRB, 2016).

\section{Initiative}

One form of initiative in the performance of bureaucracy carried out in Indonesia in the way of improving quality of public services, and the implementation of e-government, especially e-budgeting so that the use of the budget is more transparent and accountable, can 
be controlled by all parties, and avoid various irregularities. One form of application from the government to business is e-procurement in the way of procurement goods and services online through the internet is the right solution (Yusriadi, 2018b).

The existence of open data and open government, it will give birth to participation, openness, and accountability that encourage public control and participation in governance. Data openness will help public service providers to perform services well because federal supervision plays a useful role, makes it easier to realize all electronic-based government services.

Open data and open government can inspire public service providers to be more open to the community, mainly related to the use of service standards because openness can be the door to conveying suggestions, input, and criticism of useful improvements from the city. Public service innovations are carried out in some regions, such as Surabaya, Bandung, Makassar, Jakarta, and others, who have transparency public information and provide excellent service.

Innovations in Surabaya's public services, first, 6 in 1 public service which covers birth certificate, death, marriage, divorce, moving letters come, and walk out online. Secondly, the innovation of "Hot Tofu" (not afraid of being rained and not fearful of heat) is an activity to repair uninhabitable homes through a social rehabilitation program.

Third, the innovation of Economic Heroes and Young Fighters (Admin, 2018). Two innovations from the Bandung City Government, E-Satria (Self Assessment Tax Reporting Application) and Mini Lab Security program, E-Satria is an innovation to make it easier for taxpayers to pay their obligations without having to visit the office of the Regional Service and Revenue Agency (BPPD). The MiniLab Security program takes the form of directly filtering the food to be purchased by consumers so that its purity maintained (Pasha, 2018).

An innovation of Makassar City Government known as One Million Fish (Fisheries Product Quality Test Certification, So South Sulawesi Fisheries Products Remain Global) run by the Technical Implementation Unit of the Maritime and Fisheries Agency Fisheries Product Quality Office (Azis, 2018). Two innovations in the Jakarta City Government, Check and Realize (Prevent Cervical Cancer with MAPLE-S Application and HIBISCUS Cancer Detection Cars); and Civil Doyan Road innovation (System for Selecting Doctors and Timing of Outpatient Patients) (Bagja, 2018).

\section{CONCLUSION}

Bureaucracy is an administrative body that carries out tasks, policies that are set to achieve government goals. The change in the paradigm of the role and function of the government bureaucracy and its policies directed at providing the best service to citizens is a top priority. One of the significant challenges facing administration is how they can carry out activities effectively and efficiently because so far the bureaucracy has been identified with convoluted performance, long structures, full of collusion, corruption, and nepotism, and there are no definite standards.

Bureaucratic reform aimed at independence and public welfare must be by design or planned change process. By going to a proposed change, it will enable a continuous process of change. Thus the performance of the government bureaucracy in public service will be more effective and efficient by the expectations and aspirations of the community. The application 


\section{Jurnal Administrare: Jurnal Pemikiran Ilmiah dan Pendidikan Administrasi Perkantoran Volume 6 Number 1 January-June 2019. Pages 17-24}

of good governance based on information technology can use as a strategy and guidance in providing services to the public.

\section{REFERENCES}

Admin. (2018). 3 Terobosan Surabaya Masuk Top 99 Sistem Inovasi Pelayanan Publik Kemenpan RB.

Akib, H., Guntur, M., \& Salam, R. (2016). Civitas Academic Perception of "Blissful Services" for Recipient Postgraduate Program State University of Makassar, Indonesia. International Conference on Public Organization VI (ICONPO VI), 340-350. Thammsat University, Tha Prachan Campus.

Anonim. (2018). Birokrasi Efektif dan Efisien Mampu Meningkatkan Mutu Pelayanan.

Ashari, M. (2018). Mall Pelayanan Publik Dinilai Efisien.

Azis, A. (2018). Selamat. Sulsel dapat Penghargaan Top 40 Inovasi Pelayanan Publik 2018. Diserahkan JK ke Prof Nurdin.

Bagja, A. (2018). Pemprov DKI Raih 2 Penghargaan Top 40 Inovasi Pelayanan Publik.

Dharma, S., \& Patar, S. (2012). Kontigensi Perilaku Birokrasi Pemda: Reviu Hasil Penelitian Disertasi Almarhum Dr. Kadjatmiko, M. Soc. Sc. Jurnal Ilmiah Ilmu Administrasi Publik, l(1), 40-53.

Jamaluddin, J., Salam, R., Yunus, H., \& Akib, H. (2017). Pengaruh Budaya Organisasi terhadap Kinerja Pegawai pada Dinas Pendidikan Provinsi Sulawesi Selatan. Jurnal Ad'ministrare, $4(1), 25-34$.

Joeliono. (2017). Membangun Sikap Mental Disiplin Sumber Daya Manusia Aparatur dalam Pelayanan Publik.

Luthans, F. (2005). Organizational Behavior. New York: McGraw-hill.

MenpanRB, H. (2016). Menteri Yuddy : Disiplin PNS di Jakarta Meningkat.

Nurlaila. (2010). Manajemen Sumber Daya Manusia. Lepkhair.

Pasha, Y. (2018). 2 Inovasi Pemkot Bandung Masuk Top 99 Inovasi Pelayanan Publik 2018.

Prawirosentono, S. (1999). Kebijakan Kinerja Karyawan. Yogyakarta: BPFE.

Rivai, V., \& Basri. (2005). Peformance Appraisal: Sistem yang tepat untuk Menilai Kinerja Karyawan dan Meningkatkan Daya Saing Perusahan. Jakarta: Raja Grafindo Persada.

Saggaf, M. S., Akib, H., Salam, R., Baharuddin, A., \& Kasmita, M. (2018). The Quality Analysis Of Academic Services.

Saggaf, S., Salam, R., Kahar, F., \& Akib, H. (2014). Pelayanan Fungsi Administrasi Perkantoran Modern. Jurnal Ad'ministrare, 1(1), 20-27. 
Salam, R. (2015). Penerapan Fungsi Administrasi Perkantoran Modern berbasis Daya Saing Organisasi dalam menyongsong MEA 2015. SEMINAR NASIONAL "Revolusi Mental Dan Kemandirian Bangsa Melalui Pendidikan Ilmu-Ilmu Sosial Dalam Menghadapi MEA 2015” Himpunan Sarjana Pendidikan Ilmu-Ilmu Sosial Indonesia, 1, 186-190.

Salam, R., \& Rosdiana. (2016). Penerapan Fungsi Administrasi Perkantoran Modern Berbasis Daya Saing Organisasi dalam Menyongsong MEA 2015. SEMINAR NASIONAL "Revolusi Mental Dan Kemandirian Bangsa Melalui Pendidikan Ilmu-Ilmu Sosial Dalam Menghadapi MEA 2015” Himpunan Sarjana Pendidikan Ilmu-Ilmu Sosial Indonesia, 1(2016), 186-190. Fakultas Ilmu Sosial Universitas Negeri Makassar.

Sancoko, B. (2011). Pengaruh remunerasi terhadap kualitas pelayanan publik. Bisnis \& Birokrasi Journal, 17(1).

Sarman, H., Akib, H., \& Niswaty, R. (2015). Pengaruh Pengawasan Terhadap Disiplin Kerja Pegawai Pada Kantor Kecamatan Ujung Kota Parepare. Jurnal Office, 1(2), 115-122.

Simatupang, P., \& Akib, H. (2007). Potret Efektivitas Organisasi Publik: Review Hasil Penelitian. Manajemen Usahawan Indonesia, 36(1), 35-41.

Simatupang, P., \& Akib, H. (2011). Efektivitas Implementasi dan Dampak Kebijakan dalam Konteks Desentralisasi Pemerintahan. Jurnal Ilmiah Ilmu Administrasi Publik, 2(1), 1-9.

WV. (2016). Disiplin Kerja \& Etos Kerja Langkah Awal Reformasi Birokrasi.

Yusriadi. (2018a). Reformasi Birokrasi Indonesia: Peluang dan Hambatan. Jurnal Administrasi Publik (Public Administration Journal), 8(2), 178-185.

Yusriadi. (2018b). Tantangan Reformasi Birokrasi Berbasis E-Procurement di Indonesia. Publikauma: Jurnal Administrasi Publik Universitas Medan Area, 6(2).

Yusriadi, Sahid, A., Amirullah, I., Azis, A., \& Rachman, A. A. (2019). Bureaucratic Reform to the Human Resouces: A Case Study on the One-Stop Integrated Service. The Journal of Social Sciences Research. 
24 Jurnal Administrare: Jurnal Pemikiran Ilmiah dan Pendidikan Administrasi Perkantoran Volume 6 Number 1 January-June 2019. Pages 17-24 